\title{
KEWEWENANGAN DAN KEDUDUKAN MAHKAMAH KONSTITUSI TERHADAP PEMILIHAN KEPALA DAERAH BERKEWARGANEGARAAN GANDA
}

\author{
Oleh : M.Saldy \\ Mahasiswa Fakultas Syariah Dan Hukum UINAM \\ Nim : 10200120140 \\ Email :mhmmadsaldy@gmail.com
}

\begin{abstract}
Abstrak
Kewenangan Mahkamah Konstitusi menjadi kajian tersendiri dari tulisan ini. Sesuai dengan ketentuan Pasal 24 C Ayat (1) dan (2) adalah untuk mengadili pada tingkat pertama dan terakhir untuk menguji UU terhadap UUD, memutus sengketa kewenangan lembaga negara yang kewenangannya diberikan UUD, memutus pembubaran partai partai politik, dan memutus perselisihan tentang hasil pemilihan umum. Mahkamah konstitusi membatalkan keputusan KPU Sabu Raijua No.153/HK.03.1Kpt/5320/KPU-Kab/IX/2020 tentang penetapan Nomor urut dan Daftar Pasangan Calon Peserta pemilihan Bupati Sabu Raijua Tahun 2020 bertanggal 24 september 2020, sepanjang pasangan Calon Nomor urut 2 (Otient Patriot Riwu Kore dan Thobias Uly ). MK membatalkan keputusan KPU Kabupaten Sabu Raijua No 25/HK/03.1-Kpt/5420/KPU-Kab/2021 tentang penetapan pasangan calon Bupati dan Wakil Bupati terpilih dalam pemilihan Bupati Sabu Raijua Tahun 2020 bertanggal 23 Januari 2021. MK pun memerintahkan termohon untuk meakukan pemungutan suara ulang pemilihan Bupati dan Wakil Bupati Kabupaten Sabu Raijua Tahun 2020 dengan diikuti dua pasangan calon Nomor urut 3 Taken Radja Pono dan Herman Hegi Radja Haba. MK juga memerintahkan pemungutan suara ulang tersebut dilakukan dalam tenggang waktu 60 hari kerja sejak putusan di ucapkan. Dalam pertimbangan Mahkama Konsitusi,menemukan fakta Hukum bahwa Orient Patriot Riwu Kore mempunyai dua paspor. Dua paspor tersebut, yaitu paspor Republik Indonesia Nomor X746666 yang berlaku 1 April sesuai dengan keterangan Ditjen Imigrasi Kemenkunham dan Paspor Amerika Serikat Nomor 574900485 yang berlaku 10 Juli 2017 sampai dengan 9 Juli 2027.
\end{abstract}

\section{Kata kunci : Mahkamah Konstitusi, Kewenangan MK}

\section{A. Pendahuluan}

\section{a. Latar Belakang}

Pilkada serentak tahun 2020 telah berlalu, namun hal itu menyisahkan polemik yakni terkait kasus kewarganegaraan Orient P Riwu Kore selaku Bupati terpilih di Kabupaten Sabu Raijua Provinsi Nusa Tenggara Timur. Diketahui bawha status Oriet P Riwu Kore merupakan warga negara Amerika Serikat. Hal tersebut terungkap setelah Badan Pengawasan Pemilu (Bawaslu) menerima balasan surat elektronik dari kedutaan besar Amerika Serikat mengenai status kewarganegaraan Orietn P Riwu Kore. Namun menurut pengakuan dari Oriet P Riwu Kore dirinya adalah warga negara Indonesia (WNI) sah yang lahir di kota kupang 7 oktober 1965, bersekolah mulai SD hingga Perguruan Tinggi di kupang, serta Nomor Induk Kependudukan (NIK) dirinya resmi didatabase kependudukan pada diktorat jederal Kependudukan dan Pencatatan Sipil (Ditjen Dukcapil) . Orietn P Riwu Kore juga mengakui dirinya pernah memiliki paspor Amerika Serikat ketika ia masih bekerja disana. Berdasarkan hal tersebut status 
kewarganegaraan Orient P Riwu Kore saat ini dalam penelitian Kementrian Hukum dan HAM untuk menentukan apakah dia masih WNI atau sudah menjadi WNA.

\section{b. Rumusan Masalah}

Kasus kewarganegaraan Orient P. Riwu Kore bupati terpilih Sabu Raijua

\section{B. METODE PENELITIAN}

\section{a. Tujuan Penelitian ini, adalah:}

- Untuk mengetahui metode kewenangan Mahkamah Konstitusi pada Kewarganegaraan Ganda yang dimiliki kandidat terpilih

- Untuk mengetahui pertimbangan Mahkamah Kontitusi dalam meyelesaikan Problem Kewarganegaraan

- Untuk mengetahui inkosistensi tafsir konstitusi yang dilakukan oleh Hakim Konstitusi dalam menyelesaikan Kewarganegaraan ganda Bupati terpilih.

\section{b. Kegunaan Penelitian:}

\section{Teoritis}

- Bagi penulis sendiri, penelitian ini diharapkan dapat menambah wawasan penulis dan mengembangkan cakrawala berpikir penulis, khususnya Penafsiran Hukum atau Penafsiran Konstitusi.

- Bagi ilmu pengetahuan, khususnya Hukum Tata Negara, hasil penelitian ini bisa dijadikan sebagai penambah literatur dalam memperluas pengetahuan hukum masyarakat serta memberikan sumbangan pemikiran bagi Hukum Tata Negara, khususnya dalam kajian mengenai metode penafsiran hukum pada Mahkamah Konstitusi.

\section{Praktis}

- Bagi Hakim Mahkamah Konstitusi, penelitian ini diharapkan dapat memberikan masukan dalam memutuskan sesuai UUD kewarganegaraan pemilu Kepala Daerah sehingga tercapai keadilan yang substantif.

- Bagi masyarakat dan khalayak umum, penelitian ini diharapkan dapat meningkatkan kesadaran untuk berpartisipasi dalam memantau pelaksanaan dari Putusan Mahkamah Konsitusi dalam Pemilu Kepala Daerah yang sesuai pada UUD.

\section{PEMBAHASAN}

Kasus yang terjadi pada Pilkada kabupaten sabu raijua karna Orietn P Riwu Kore memiliki paspor warganegara Amerika serikat. Berdasar dari aturan dan berbagai persyaratan yang berlaku Berdasarkan ketentuan dalam pasal 7 UU Pilkada dapat kita ketahui bahwa syarat mutlak bagi seorang untuk mencalonkan diri sebagai Gubernur, Wakil Gubernur, Bupati, Wakil Bupati, Walikota, Wakil Walikota adalah seorang warga negara Indonesia. Hal serupa juga dinyatakan dalam ketentuan pasal 4 peraturan komisi pemilihan umum No.1 Tahun 2020 tentang perubahan ketiga asa peratiran komisi pemilihan umum No.3 Tahun 2017 tentang pencalonan Gubernur dan Wakil Gubernur . Bupati dan 
Wakil Bupati. Walikota dan Wakil Walikota (selanjutnya disebut PKPU 1/2020). Bupati sabu raijua cacat hukum karna Orient P Rewu Kore memiliki kewarganegaraan ganda. Dan ditelusuri putusan MK Dan Mahkama konsitusi membatalkan keputusan KPU Sabu Raijua No.153/HK.03.1-Kpt/5320/KPU$\mathrm{Kab} / \mathrm{IX} / 2020$ tenatang penetapan Nomor urut dan Daftar Pasangan Calon Peserta pemilihan Bupati Sabu Raijua Tahun 2020 bertanggal 24 september 2020, sepanjang pasangan Calon Nomor urut 2 ( Otient Patriot Riwu Kore dan Thobias Uly ). Keempat, MK membatalkan keputusan KPU Kabupaten Sabu Raijua No 25/HK/03.1-Kpt/5420/KPU-Kab/2021 tentang penetapan pasangan calon Bupati dan Wakil Bupati terpilih dalam pemilihan Bupati Sabu Raijua Tahun 2020 bertanggal 23 Januari 2021. MK pun memerintahkan termohon untuk meakukan pemungutan suara ulang pemilihan Bupati dan Wakil Bupati Kabupaten Sabu Raijua Tahun 2020 dengan diikuti dua pasangan calon Nomor urut 3 Taken Radja Pono dan Herman Hegi Radja Haba. MK juga memerintahkan pemungutan suara ulang tersebut dilakukan dalam tenggang waktu 60 hari kerja sejak putusan di ucapkan. Dalam pertimbangan Mahkama Konsitusi,menemukan fakta Hukum bahwa Orient Patriot Riwu Kore mempunyai dua paspor. Dua paspor tersebut, yaitu paspor Republik Indonesia Nomor X746666 yang berlaku 1 April sesuai dengan keterangan Ditjen Imigrasi Kemenkunham dan Paspor Amerika Serikat Nomor 574900485 yang berlaku 10 Juli 2017 sampai dengan 9 Juli 2027.

\section{Undang - undang WNI tidak boleh berkewarganegaraan ganda}

Dalam Undang - Undang, WNI dilarang mimiliki kewarganegaran ganda. Pada pasal 23 Undang Undang 12 tahun 2006 tetntang kewarganegaraan menjelaskan hal apa saja yang dapat menghilangkan status WNI seseorang. Salah satunya jika orang tersebut telah menjadi warga negara lain atau kemauannya sendiri. Pasal 23 Undang - Unang kewarganegaraan terdiri dari huruf A sampai I. Berikut bunyi ke 9 poin di pasal 23 yang menjadikan seseorang tak lagi berstatus WNI.

Pasal 23

a . memperoleh kewarganegaraan lain atas kemauanny sendiri.

b . tidak menolak atau tidak melepaskan kewarganegaraan lain, sedangkan orang yang bersangkutan mendapatkan kesempatan untuk itu.

c . dinyatakan hilang kewargnegaraannya oleh presiden atas permohonannya sendiri, yang bersangkutan sudah berusia 18 tahun lalu sudah kawin, bertempat tinggal di luar negri, dan dengan dinyatakan hilang kewarganegaraanRepublik Indonesia tidakmenjadi tanpa kewarganegaraan.

d. masuk dalam dinas tentara asing tanpa izin terlebih dahulu dari presiden.

e . secara sukarela masuk dalam dinas negara asing, yang jabatan dalam dinas semcam itusi indonesia sesuai dengan ketentuan peraturan undang - undang hanya dapat di jabat oleh warga negara Indonesia

f . secar sukarela mengangkat sumpah atau menyatakan janji setia kepada negara asing atau bagian dari negara asing tersebut.

g. tidak diwajibkan tetapi turut serta dalam pemilihan sesuatu yang bersifat ketatanegaraan untuk suatu negara asing.

h. mempunyai paspor atau surat yang bersifat paspor dari negara asing atau surat yang dapat diartikan sebagai tanda kewarganegaraan yang masih berlaku dari negara lain atas namanya,atau.

i . bertempat tinggal di luar wilayah negara Republik Indonesia selama 5 tahun terus menerus bukan dalam rangka dinas, tanpa alsan yang sah dan dengan sengaja tidak 
menyatakan keinginannya untuk tetap menjadi warga negara indonesia sebelum jangka waktu 5 tahun itu berakhir, dan setiap 5 tahun berikutnya yang bersangkutan tidak mengajukan pernyataan ingin tetap menjadi WNI kepada perwakilan RI yang wilayah kerjanya meliputi tempat tinggal yang bersangkutan padahal perwakilan RI tersebut telah memberitahukan secara tertulis kepada yang bersangkutan, sepanjang yang bersangkutan tidak menjadi tanpa kewarganegaraan. Dari penjabaran peraturan mengenai kewarganegaraan seorang kepala daerah tidak boleh memiliki warga negara ganda. warga negara indonesia tidak boleh memiliki kewarganegaraan ganda

\section{Peraturan kewarganegaraan Republik Indonesia}

Kewarganegaran RI sebelum berlakunya UU No. 12 tahun 2006 untuk melaksanakan ketentuan pasal 26 undang - undang dasar 1945, dibuatlah undang - undang pelaksanakaan, yakni undang - undang yang mengatur tentang kewarganegaraan indonesia. Sejak merdeka tanggal 17 agustus 1945 sampai sekarang undang - undang mengenai kewarganegaraan indonesia adalah sebagai beriku:

1. Undang - undang No. 3 tahun 1946 tentang warganegara dan penduduk indonesia undang - undang No. 3 tahun 1946 disetuji bersama oleh pemerintah dengan badan pekerja komite nasional indonesia pusat (BP KINP) dan diundangkan pada tanggal 10 april 1946. Namun pada tanggal 27 februari 1947, pemrintah RI dengan persetujuan KNIP mengeluarkan undangundang No. 6 tahun 1947 tentang perubahan undanh - undang No. 3 tahun 1946 tentang warga negara dan penduduk indonesia. Undang - undang No.3 tahun 1946 jo undang undang No. 6 tahun 1947. Menurut pasal 1 undang - undang No.3 tahun 1946 penjelesan tentang siapakah warga negara indonesia (winarno, hal. 108 -114)

2 . undang - undang No.2 tahun 1958 tentang persetujuan antara RI - RRT mengenai dwikewarganegaraan untuk menentukan pilihannya, apakah ia akan melepaskan kewarganegaraan RRC dan menjadi warganegaraan indonesia, atau tetap menjadi warganegara RRC dengan kehilangan kewarganegaraan indonesia. Kewajiban memilih itu hanya di bedakan kepada orang dewasa (telah berumur 18 tahun atau pernah kawin). Pemilihan kewarganegaraan itu dilakukan dengan menyatakan kepada petugas - petugas negara, kewarganegaraan mana, dengan disertai surat- surat keterangan diri serta keluarga. Anak - anak yanf belum dewasa menyatakan pilihannya dalam waktu satu tahun setelah mereka dewasaa. Bagi dwikewarganegaraan yang dewasa tidak menyatakan pilihannya dalam waktu 2 tahun berlaku dengan ketentuan.

3. undang - undang No. 62 tahun 1958 tentang kewrganegaraan indonesia undang - undang No. 62 tahun 1058 tentang kewarganegaraan indonesia (Lembaga negara tahun 1958 nomo 113) mulai berlaku sejak diundangkan pada tanggal 1 agustus 1958. Beberapan bagian dari undang - undang ini, yaitu mengenai ketentuan - ketentuan siapa yang menjadi warga negara indonesia, status anak dan cara - cara kehilangnan kewarganegaraan, ditetapkan berlaku surat tanggal 27 september 1949. Dasar hukum dari undang - undang ini adalah UUD S tahun 1950 khususnya pasal 5 san 144 UUDS

4. undang - undang no. 3 tahun 1976 tentang perubahan pasal 18 UU no. 62 tahun 1958 tentang kewarganegaraan Republik Inonesia pasal 17 huruf K UU no. 62 tahun 1958 memberikan kewajiban bagi warga negara RI yang bertempat tinggal di luar negri lain dari pada untuk mrnjalankan dinas negara, guna menyatakan keinginan untuk tetap menjadi warga negara RI dalam jangka 5 tahun yang pertama dan selanjutnya untuk siap 2 tahun. 
Dalam masa itu tidak semua warga negara RI yang tinggal di luar negri dapat memenuhi kewajiban tersebut bukan karena kelalaian melainkam akibat dari keadaan di luar negri kesalahannya, sehingga ia terpaksa dia tidak menyatakan keinginannya tersebut tepat pada waktunya karena pasa 18 tidak menampung orang - orang tersebut, maka perlu diadakan perbubahan bertahap pasal 18 UU no. 62 tahun 1958. Adapun yang mengenai orang yang berhak menggunakan kesempatan pasal 18 ayatb 2 adalah orang - orang yang pada waktunya mulai berlakunya UU NO. 62 Tahun 1958 adalah warga negara RI dan selama ini menujukkan kesetiaannya kepada negara RI. Dengan demikian mereka yang berkewarganegaraan asing, mereka yang tanpa kewarganegaraan karena kehiangan kewarganegaraan RI atau mereka yang telah memilih menjadi warga negara dari negara lain, tidak dapat menggunakan kesempatan ini.

Istilah kewarganegaraan menurut ketentuan UU NO. 12 tahun 2006 adalah segala ikhwal yang berhubungan dengan warga negara (pasal 1). Oleh kewarganegaraan, maka kewarganegaraan mencakup hal- hal, antara lain

1. penentuan tentang siapa saja yang termasuk warga negara

2. cara menjadi warga negara atau pewarganegara

3. tentang kembali kewarganegaraan yang hilanh.

adapun ketentuan pokok yang diatur dalam UU NO. 12 tahun 2006 adalah sebagai berikut.

1. tentang siapa yang menjadi warga negara indonesia

2. tentang syarat dan kata cara memperoleh kewarganegaraan RI

3. tentang kehiangan warganegara RI

4. tentang syarat dab tata cara memperoleh kembali kewarganegaraan RI

5. tentang ketentuan pidana

secara umum dalam undang - undang dinyatakan bahwa menjadi WNI adalah orang - orang bangsa indonesia asli dan orang - orang lain yang disahkan dengan undang - undang sebagai warganegara (pasal 2). yang dimaksud dengan orang-orang bangsa indonesia asli, adalah orang indonesia yang menjadi warganegara negara indonesia sejak kelahirannya dan tidak pernah menerima warganegara lain atas kehendaknya sendiri. Sedangkan isi dari UU NO. 12 tahun 2006 adalah sebagai berikut .

1. tentang siapa warga negara indonesia, dinyatakan bahwa yang menjadi warga negara indonesi termasuk dalam pasal 4 atau winarno, hal. 128-130

2. tentang cara memperoleh kewarganegaraan $\mathrm{Rl}$, menurut undang- undang unu dapat dilakukan dengan :

- melalui permohonan (pasal 8-9)

- melalui pernyataan (pasal 19)

- melalui pemberian kewarganegaraan (pasal 20)

- melalui pernyataan untuk memilih kewarganegaraan, dinyatakan bahwa kewarganegaraan(wainarno, ha. 131-132)

3. tentang kehiangan kewarganegaraan, dinyatakan bahwa kewarganegaraa RI hilang, jika bersangkutan : (pasal 23) atau winarno, hal. 132-136) 
Dalam daftar persyaratan pencalonan kepala daerah di indonesia tentunya harus memiliki syarat utama sebagai warga negara Republik Indonesia. Dalam ketentuan sytaratnya hal ini penting untuk digaris bawahi, karena hal ini menyangkut loyalitas pengabdian sang pemimpin terhadapa daerah yang tengah di pimpinnya kedepa. Jika syrata pertama di abaikan, dengan sendirinya, seorang yang berinsiatif mencalonkan diri sebagai kepala daerah sudah dibatalkan. Hal ini, tidak hanya berlaku bagi ketentuan terkait menjadi calon pemimpin. Syarat-syarat berlaku lain jika terkait tugas dan kewenangan di negara ini, pasti mengedepankan status kewarganegaraan

\section{Paca - putusan MK, KPU evaluasi PKPU Pencalonan Pilkada}

Pada saat MK melakukan rapat secara daring, pada saat itu Mahkamah Konsitusi mengeluarkan putusan tenteng sengketa Pilkada Sabu Raijua, Nusa tenggara timur, akan dijadikan hahan evaluasi dan penyempurnaan peraturan KPU atau PKPU tentang pencalonan kepala daerah. Hal ini dilakukan atau kejadian lolosnya warga negara asing calon kepala daerah tidak kembali terulang. Anggota komisi pemilihan umum (KPU), I Dewa Kade Wiarsa Raka Sandi, di Jakarta, jumat (16/4/2021), mengatakan, KPU akan mencermati putusan Mahkamah Konsitusi (MK) terkait perselisihan hasil pilkada sabu raijua yang mengidentifikasi pasangan Orient P Riwu Kore - Thobias Uly. Jika dalam evaluasi ditemukan ada permasalahan dalam implementasinya, PKPU Nomor 1 tentang pencalonan pilkada akan direvisi. Kajian terhadap dua putusan itu, yakni sabu raijua dan boven digoel, menjadi bahan pertimbangan hukum untuk menyempurnakan PKPU agar kejadian di kedua daerah tidak terulang di pilkada mendatang. Saat ini, biro pengaturan perundang undangan KPU juga tengah mengkaji putusan Mahkamah Konsitusi terkait sengketa pilkada perselisihan hasil pilkada boven digoel. Kajian terhadap dua putusan itu, yakni sabu raijua dan boven digoel, menjadi bahan pertimbangan hukum untuk menyempurnakan PKPU agar kejadian di kedua daerah tidak terulang di pilkada pendatang. "Menuju pemilu dan pilkada serentak 2024, kami masih memiliki sedikit waktu untuk mengevaluasi dan menyempurnakan PKPU,termasuk PKPU tentang pencalonan pilkada, karena aturan perundangundangan yang di gumanakan masih sama." kata Raka.

\section{Status warga negara Orient tidak boleh dilantik sebagai Bupati}

Kita menyayangkan dan sangat kecewa terhadpa polemik status kewarganegaraan Bupati terpilih Sabu Raijua, Nusa Tenggara Timur (NTT) pada pilkada 2020 yang lalu, IEW mengungkapkan, kasus kel pertama terjadi. Pada tahun 2016, Presiden Jokowi juga sudah pernah keliru dengan melantik Arcandra Tahar sebagai mentri ESDM yang saat itu mengantongi paspor Amerika Serikat sejak tahun 2012. "Pemrintah dengan segala sumber hukumnya harusnya belajar dari kejadian tersebut" Karenanya, IEW menilai bahwa, terpilihnya Orient $P$ Riwu Kore sebagai Bupati Kabupaten Sabu Raijua bukti nyata indonesia tidak pernah belajar dan tidak pernah berbenah dari kejadian masa lalu. Kemnentrian Dalam Negri (Kemendagri) telah mengklarifikasi langsung kepada Orient Riwu Kore , Bupati terpilih Sbu Raijua, NTT berdasarkan pengakuan, Orient pernah memiliki paspor Amerika serikat (AS) tanpa melepaskan status kewarganegaraan indonesia. Direktur Jendral Kpendedukan (Dirjen Dukcapil) Kemendagri Zudan Arif Faktulloh mrnyatakan, klarifikasi dilakukan setelah menjadi berbincangan publik status kewarganegaraan Orient Rieu Kore. Karena diduga cacat sebagai warga negara AS. Sedangkan berdasarkan koordinasi dengan Kemenkunham bahwa, status kewarganegaran Orient masih dalam pengkajian untuk menetukan bahwa yang 
bersngkutan masih WNI atau sudah menjadi WNA. IEW mengaku turtu mengamati dan menilai bahwa, yang dilkukan penyelenggara sudah di anggap baik dan sesuai. KPUD Sabu Raijua bahkan melakukan klarifikasi ke Dinas Kependudukan dan catatan sipil (Dukcapil) kota kupang mengenai keabasahan KTP Orient seperti yang di pertanyakan bawaslu tersebut. Bahkan, apresiasi juga harus kita berikan kepada Bawaslu yang tentu saja langkah bijak dengan mengirim surta kepada kedutaan AS pada tanggal 15 september 2020, perihalpermohonanan informasi data kewarganegaraan Orient. " Kita minta kepada Kemendagri atau Pemptov NTT jika Orient P Riwu Kore terbukti memiliki kewarganegaraan Pamansam, maka tidak boleh ad pelantikan terhadap dirinya. Kenapa? karena memang tidak sah dia (Orient) sebagai kandidat pilkada." Pihak menyebutkan, pasa 7 undang - undang Nomot 10 Tahun 2016 tentang pilkada dengan jelas menyebutkan syarat utama bisa menjadi calon kepala daerah adalah warga negara indonesia (WNI) . Karenanya, meski Orient P Riwu Kore telah terpilih, tettpi IEW meninta tidak boleh dilakukan pelantikan, karna hal tersebut mencoreng martabat bangsa isndonesia sebagai sebuah negara yang berdaulat." Hal ini karena, Indonesia tidak menganut dwi - kewarganegaraan, itu jelas, sebagaimana ditegaskan pada pasal 23 undang- undang kewarganegaraan Nomor 12 tahun 2006. Kemudian, seseorang kehilangan statusnya sebagai WNI apanilah telah memperoleh kewarganegaraan lain atas kemauannya sendiri dan secara sukarela mengangkat sumpah atau menyatakan janji setia kepada negara asing atau baguan dari negara asing tersebut. Dia juga menyebutkan, jika mengacu pada pasal 9 UU 12 tahun 1006, seseorang harus mengajukan permohonan kembali sebagai WNI pada saat sudah bertempat tinggal di indonesia selama lima tahun berturut -turut atau 10 tahun tidak berturut-turut. Meski banyak pakar hukum yang mrngatakan bahwa Orient P Riwu Kore tetap bisa dilantik dan kemudian langsung dihentikan, namun IEW mengacu pada pasal 164 ayat 4 undang - undang Nomor 10 tahun 2016 tentang pilkada, bahwa calon kepala daerah tidak bisa di lantik karena meninggal dunia, berhalangan tetap, atau mengundurkan diri. Karena, apa yang sudah dilakukan Orient merupakan sebuah pelanggaran administrasi kewarganegaraan yang mencakum serius, maka bisa ia dianggap berhalangan tetap dan tidak dilantik sesuai peraturan tersebut. Meski begitu, hasil pemilu tetap sah san tidak dilakukan pemungutan suara ulang. Sebap,pasangan Orient, yakni wakil Bupati terpilih sabu raijua, Thobias Uly tetap memenuhi syarat dan boleh dilantik. "Tetapi, kejadian ini harus diselesaikan oleh semua pihak yang bertanggung jawa, tidak hanya KPU dan Bawaslu sebaai penyelenggara, namun juga pemerintah (DiSdukcapil, Kemendagri, Kemlu, Kemenkumham, dII) terhadap tertib administrasi kependudukan di indonesia." Menurut Undang - undang trsebut trdapat pidana penjara dan sanksi 3 tahun dan 6 tahun jika memang terbukti memberikan keterangan palsu atau tidak benar atau menggunakan surat palsu seolah - olah sebagai surat yang sah tentang suatu hal yang di perlukan bagi persyaratan intuk menjadi Calon Bupati. $s$

Mahkamah Konstitusi (MK) menggelar sidang lanjutan perkara Perselisihan Hasil Pemilihan (PHP) Bupati Sabu Raijua Tahun 2020 pada Selasa (6/4/2021) di Ruang Sidang Pleno MK. Perkara yang teregistrasi Nomor 133/PHP.BUP-XIX/2021 ini diajukan oleh Pasangan Calon Nomor Urut 1 Nikodemus N. Rihi Heke dan Yuhanis Ulu Kale. Agenda persidangan tersebut adalah mendengarkan keterangan Ahli dan Saksi yang dihadirkan para pihak.

Margarito Kamis selaku Ahli yang dihadirkan Pemohon dalam keterangannya mengatakan UUD 1945 hanya akan memberikan hak kepada warga negaranya untuk memilih dan melaksanakan penyelenggara kekuasaan negara. Dalam keterangan ini, Margarito mengemukakan dalam 
konsep citizen atau kewarganegaraan tidak pernah tidak dipertalikan dengan orang-orang yang ada di satu daerah yang sejak awal bersepakat menjadi suatu komunitas dalam suatu tatanan sosial yang diakui sebagai pribadi yang merdeka dan memiliki hak serta kewajiban yang sama. Artinya, citizen adalah mereka yang tinggal dalam kota dan memiliki hak serta bebas untuk berpartisipasi dalam pemerintahan. Oleh karenanya, Margarito menegaskan bahwa hal ini harus pula dipertalikan dengan posisi orang di dalam komunitas itu dan menunjuk adanya hak menjalankan partisipasi dalam penyelenggaraan kehidupan kemasyarakatan.

Dalam kerangka ini, Margarito mencermati usai Revolusi Prancis konsep citizen ditunjukkan pula dalam UUD 1945 bahwa orang-orang yang berasosiosi dalam suatu kedaulatan adalah sebagai pemegang kekuasaan tertinggi di negara tersebut dan hanya mereka pula yang memegang seluruh hak dan kewajiban membentuk pemerintahan negaranya. Cara pandang ini, kata Margarito, termaktub dalam UUD 1945 bahwa kedaulatan hanya ada di tangan rakyat.

"Maka citizen tidak sama dengan penduduk. Oleh karenanya kedaulatan tidak lain beresensi pada pelaksanaan kekuasaan. Sebab itulah UUD 1945 mengatakan hanya WNI yang bersamaan kedudukan hukum dalam permintahan dan hanya mereka pulalah yang bisa ikut melaksanakan pemerintahan dan tidak lain dari itu," jelas Margarito yang menghadiri sidang secara virtual dari kediamannya.

\section{Tidak Sah}

Sementara itu berkaitan dengan akibat hukum jika orang asing mendaftarkan diri menjadi kepala daerah dan dinyatakan seluruh dokumennya sah oleh KPU, Margarito menilai hal ini dapat dinyatakan seseorang tersebut tidak punya hak dan tidak pula memenuhi syarat hukum untuk menjadi kepala daerah. Apabila syarat kewarganegaraan tidak terpenuhi, maka demi hukum semua hal yang terkandung di dalam pengajuan syarat dan lainnya tersebut pun dapat dinyatakan tidak sah. Sehingga yang bersangkutan tidak punya hak apapun dalam pemilihan.

Jika KPU mengatakan seseorang tersebut memenuhi syarat saat pendaftaran, hal demikian hukumnya yang bersangkutan harus dinyatakan tidak ada sejak awal kendati KPU mengeluarkan keputusan sahnya. Lagi pula, ketika ada fakta yang mengatakan dan sifatnya valid secara hukum, maka hukumnya tidak memenuhi syarat sejak awal. Demikian pula konsekuensinya dengan wakil bupati yang berpasangan dengan yang bersangkutan. Dalam kenyataannya wakil pun harus dinyatakan tidak sah karena kedua pasangan ini adalah satu kesatuan hukum, administrasi, dan tidak ada hukum pemilihan yang hanya dapat diikuti oleh salah satu orang saja. Maka dengan tak terpenuhinya syarat dari salah satu paslon, maka wakilnya pun memikul tanggung jawab yang sama," jelas Margarito.

\section{Pindah Domisili}

Hendri Dunant selaku saksi yang dihadirkan Pemohon dalam kapasitasnya sebagai Ketua RW mengatakan bahwa Orient Patriot Rewu Kore mengajukan permohonan untuk surat domisili pindah alamat dari wilayah Tanjung Priok, Jakarta Utara ke wilayahnya di daerah Melawai, Jakarta Selatan. Diakuinya, berpedoman pada registrasi tertanggal 9/12/2019 dirinya menerima pengajuan pindah domisili berupa surat pengantar dari RT 03/RW 07 Tanjung Priok, Jakarta Utara ke wilayah Jakarta Selatan. "Saya bertemu langsung dengan Orient dan memberikan stempel untuk selanjutnya yang bersangkutan dapat mengurus keperluan pemindahan KTP ke kelurahan. Jadi, saya tidak tahu apakah Orient memiliki KTP apa saja saat itu," sampai Henri. Sementara itu, Samuel P. selaku Tim Data Paslon 01 dalam keterangan Saksi Pemohon mengatakan menemukan 
kejanggalan pada KTP Orient saat mendaftarkan diri sebagai pasangan calon Bupati dan Wakil Bupati Kabupaten Sabu Raijua Tahun 2020. Dirinya mendapati NIK yang bersangkutan tidak sesuai dengan daerah Kupang. Mestinya, jelas Samuel, kode untuk NIK wilayah Kupang adalah 5371, sementara kode yang ada pada NIK Orient adalah 3172 yang dikeluarkan oleh Disdukcapil daerah Kupang. Selanjutnya Alberky M. selaku Tim Penghubung Paslon 01 dengan KPU dalam kesaksiannya mengatakan telah mengetahui status kewarganegaraan Orient sejak 2018. Saat itu hal ini ramai dibicarakan masyarakat di Sabu Raijua karena Orient mensponsori pertandingan sepak bola yang diselenggarakan di daerah tersebut.

\section{Perkembangan Globalisasi}

Maruarar Siahaan selaku Ahli yang dihadirkan Pihak Terkait mengatakan asas kewarganegaraan di Indonesia adalah asas tunggal. Tetapi juga dibuka kemungkinan adanya kewarganegaraan ganda terutama setelah adanya norma hukum UU Nomor 12 Tahun 2006. Sehingga dalam kaitan dengan perkara a quo, dirinya melihat persoalan ini suatu perkembangan dari globalisasi khususnya pula bagi orang Indonesia. Dalam sudut pandangnya, ia menyarankan dalam perkara a quo memberikan kesempatan bagi pemerintah untuk menilai serangkaian keputusan, terlebih lagi permasalahan pemilihan telah sampai pada penetapan kepala daerah terpilih. Oleh karena itu, dari perkara ini diharapkan dapat menjadi bahan bagi pemerintah dalam memutuskan akan melantik atau tidak atas terpilihnya kepala daerah ini. Dalam pandangannya, Maruarar menyatakan saat ini dunia telah berada dalam tahap satu kesatuan global sehingga tidak tertutup kemungkinan dibutuhkannya diaspora. Mengingat ilmu dan modal yang dimiliki para diaspora sangat dibutuhkan dalam pembangunan Indonesia. Dalam perkara ini, Orient belumlah kehilangan kewarganegaraan Indonesia karena belum ada pernyataan pribadi untuk melepas kewarganegaraannya. "Oleh karenaya dual citizen itu adalah suatu keniscayaan untuk membangun Indonesia secara timbal balik terutama bagi warga negara yang tidak dikehendakinya secara sendiri untuk memiliki kewarganegaraan lain, seperti untuk pekerjaan dan lainnya," sampai Maruarar dalam sidang Pleno Khusus yang dipimpin Ketua MK Anwar Usman dengan didampingi delapan hakim konstitusi lainnya.

\section{Prosedur Kehilangan Kewarganegaraan}

Nurudin selaku Ahli Pihak Terkait menerangkan terkait kewarganegaraan ganda terbatas yang dapat dimiliki seseorang hingga usia 18 tahun dan setelahnya yang bersangkutan harus memilih untuk berkewarganegaraan Indonesia atau lainnya. Sehubungan dengan ini, terhadap adanya permasalahan implementasi seseorang kehilangan kewarganegaraan Indonesia, Nurudin menjabarkan hal demikian terjadi di antaranya apabila seseorang telah memperoleh kewarganegaraan lain atas kemauan sendiri, tidak melepaskan kewarganegaraan lain, dinyatakan hilang kewargannegaraan yang dinyatakan kepada Presiden, dan memiliki paspor atau dokumen resmi lainnya dari negara lain sebagai tanda kewarganegaraan lain atas namanya. Sebagai informasi dalam sidang terdahulu Pemohon meminta Mahkamah membatalkan Surat Keputusan Komisi Pemilihan Umum (KPU) Kabupaten Sabu Raijua Nomor 25/HK.03.1-Kpt/5320/KPUKab/I/2020 tentang Penetapan Pasangan Bupati dan Wakil Bupati Sabu Raijua Tahun 2020 bertanggal 16 Desember 2020. Hal ini terkait temuan Bawaslu Kabupaten Sabu Raijua yang menyebutkan Bupati terpilih atas nama Orient Patriot Rewu Kore merupakan warga negara Amerika Serikat. Oleh karena itu, Pemohon meminta MK hadir untuk kepastian hukum terhadap permasalahan ini. Sejatinya Pemohon sangat keberatan dengan keputusan KPU Sabu Raijua 
(Termohon) karena menurut temuan Bawaslu pasangan calon yang menang tidak memenuhi syarat sebagai Pasangan Calon Bupati dan Wakil Bupati. Menurut Pemohon, keputusan Termohon tersebut bertentangan dengan Pasal 10 ayat (1) UU 30/2014 tentang Administrasi Pemerintahan. Atas fakta hukum tersebut, Pemohon dalam Petitum memohonkan agar Mahkamah menyatakan Pasangan Calon Nomor Urut 2 tidak dapat cakap sebagai Pasangan Calon Bupati dan Wakil Bupati Kabupaten Sabu Raijua karena melanggar Keputusan KPU Nomor 1 Tahun 2020 Pasal 1 Butir 18. Kemudian, menetapkan Pemohon sebagai pemenang pemilihan Bupati dan Wakil Bupati Kabupaten Sabu Raijua Tahun 2020 dan/atau setidaknya dilakukan Pemungutan Suara Ulang di Kabupaten Sabu Raijua.

Maka dari itu, tepat pada hari kamis 15 april 2021 MK memutuskan untuk mendiskualifikasi pasangan calon nomor urut 2 dalam pemilihan bupati dan wakil bupati Sabu Raijua yakni, Orient Patriot Riwu Kore Dan Thobias Uly. Putusan itu dibacakan oleh ketua MK Anwar Usman dalam sidang sengketa hasil pilkada 2020 yang disiarkan secara. Anwar Mengatakan, pihaknya membatalkan semua keputusan KPU Sabu Raijua mulai dari penetapan pasangan calon di pilkada 2020 hanya sepanjang yang berkaitan dengan pasangan calon nomor urut 2 Orients-Thobias. serta memerintahkan adanya pemungutan suara ulang tanpa diikuti oleh Orients-Thobias. Selain itu, MK juga memerintahkan KPU dan Bawaslu RI untuk melakukan supervise pelaksanaan amar putusan ini.

\section{KESIMPULAN}

Kasus yang terjadi pada Pilkada kabupaten sabu raijua karena Orietn P Riwu Kore memiliki paspor warganegara Amerika serikat. Dalam daftar persyaratan pencalonan kepala daerah di indonesia tentunya harus memiliki syarat utama sebagai warga negara Republik Indonesia. Dalam ketentuan syaratnya hal ini penting untuk digaris bawahi, karena hal ini menyangkut loyalitas pengabdian sang pemimpin terhadap daerah yang tengah di pimpinnya kedepan. Jika syarat pertama di abaikan, dengan sendirinya, seorang yang berinsiatif mencalonkan diri sebagai kepala daerah sudah dibatalkan. Hal ini, tidak hanya berlaku bagi ketentuan terkait menjadi calon pemimpin. Syarat-syarat berlaku lain jika terkait tugas dan kewenangan di negara ini, pasti mengedepankan status kewarganegaraan. Putusan MK tentang pilkada sabu raijua, lanjut dia menjadi bahan evaluasi bagi penyelenggara dan peserta agara semakin jujur dan terbuka memberikan dokumen administrasinya. Sebap, dalam perosesnya, KPU dinilai telah melaksanakan tahapan sesuai regulasi yang ada. Dalam daftar persyaratan pencalonan kepala daerah di indonesia tentunya harus memiliki syarat utama sebagai warga negara Republik Indonesia. Dalam ketentuan sytaratnya hal ini penting untuk digaris bawahi, karena hal ini menyangkut loyalitas pengabdian sang pemimpin terhadapa daerah yang tengah di pimpinnya kedepa. Jika syrata pertama di abaikan, dengan sendirinya, seorang yang berinsiatif mencalonkan diri sebagai kepala daerah sudah dibatalkan. Hal ini, tidak hanya berlaku bagi ketentuan terkait menjadi calon pemimpin. Syarat-syarat berlaku lain jika terkait tugas dan kewenangan di negara ini, pasti mengedepankan status kewarganegaraan. Putusan MK tentang pilkada sabu raijua, lanjut dia menjadi bahan evaluasi bagi penyelenggara dan peserta agara semakin jujur dan terbuka memberikan dokumen administrasinya. Sebap, dalam perosesnya, KPU dinilai telah melaksanakan tahapan sesuai regulasi yang ada.

Maka dari itu, MK memutuskan untuk mendiskualifikasi pasangan calon nomor urut 2 dalam pemilihan bupati dan wakil bupati Sabu Raijua yakni, Orient Patriot Riwu Kore Dan Thobias Uly. 
Putusan itu dibacakan oleh ketua MK Anwar Usman dalam sidang sengketa hasil pilkada 2020 yang disiarkan secara . Anwar Mengatakan, pihaknya membatalkan semua keputusan KPU Sabu Raijua mulai dari penetapan pasangan calon di pilkada 2020 hanya sepanjang yang berkaitan dengan pasangan calon nomor urut 2 Orients-Thobias. serta memerintahkan adanya pemungutan suara ulang tanpa diikuti oleh Orients-Thobias. Selain itu, MK juga memerintahkan KPU dan Bawaslu RI untuk melakukan supervise pelaksanaan amar putusan ini. 


\section{DAFTAR PUSTAKA}

https://www.pikiran-rakyat.com/nasional/pr-011379372/polemik-warga-amerika-serikat-jadi-bupatiterpilih-di-ntt-kinerja-kpu-dikritisi

https://www.jpnn.com/news/bupati-sabu-raijua-terpilih-orient-p-riwu-kore-saya-wni-sah

https://www.kompas.id/baca/polhuk/2021/04/16/pascaputusan-mk-kpu-evaluasi-pkpu-pencalonanpilkada?status_register=register\&status_login=login

https://www.lead.co.id/status-warga-as-iew-orient-tidak-boleh-dilantik-sebagai-bupati/ https://news.detik.com/berita/d-3274681/uu-wni-tak-boleh-berkewarganegaraan-ganda 